\title{
Chinese amend policy on sterilisation for genetic reasons
}

\author{
M arcus Pembrey and Ségolène A ymé \\ on behalf of the ESHG Public and Professional Policy Committee
}

The Chinese Ministry of $\mathrm{Health}$ plans to offer some clarifications of a few articles in the Maternal and Infant $\mathrm{H}$ ealth $\mathrm{C}$ are L aw (source : $\mathrm{X}$ inhua $\mathrm{N}$ ews A gency, B eijing, 13 A ugust, 1998). The clarifications will explain that sterilisation will only be allowed with the consent of a couple or their guardians. The names of genetic diseases serious enough to be considered inappropriate for child-bearing will be established in accordance with the authoritative opinions of geneticists both at home and abroad, said the $\mathrm{M}$ inister of $\mathrm{Health}$. $\mathrm{He}$ also suggested that the international principle of 'informed consent' be added to the general principle of the law. The Commission of L egislative A ffairs of the $\mathrm{N}$ ational People's Congress Standing Committee has already accepted this.

China had come under intense international criticism since the implementation of the law on 1 J une 1995. The E uropean Society of Human Genetics and the European A lliance of $G$ enetic Support Groups have joined forces to urge the People's R epublic of China to drop compulsory childlessness on genetic grounds from their new law. A statement ( $\mathrm{E}$ ur J H um Genet 1995; 3: 5, 329-330) was approved by the ESH G board at the 1995 Berlin meeting and presented to the Chinese authorities through the Chinese A mbassador in London. The European governments were encouraged to raise objections at the 4th U nited Nations World Conference on Human Rights and Women, held in Beijing in September 1995. The ESH G statement recognised the great progress made by the People's R epublic of China in provision of high quality health care to the people, and supported their recognition of the need to address the burden that genetic disease brings to families and society, but rejected premarital selection as a violation of human rights. A report on the Chinese law was issued by the HUGO Ethics Committee (Genome Digest 1997; A pril 6-8).

Further progress was encouraged by the debate over the International Congress of $G$ enetics held in B eijing in A ugust 1998. Several societies, including the B ritish, US, Dutch and A rgentinian Genetics Societies have refused to pay for representatives to attend. 0 ther societies, including the European Society of Human Genetics and the Human Genetics Society of Australasia, thought dialogue with Chinese colleagues was likely to be the best means of achieving a change in the law and the ESHG/EAGSG statement was presented again. A ccording to an article published in the International Herald Tribune (18 A ugust 1998), this statement and others like the HUGO Ethics report, are likely to have been influential.

The issue of the Chineses law in 1995 underlined the necessity for a forum for groups dedicated to all aspects of human genetics, including research, clinical practice, professional and lay education at the international level. This forum is now the International Federation of Human Genetics Societies (http://www.infobiogen.fr/ agora/ifhgs/), the purpose of which is to facilitate communication about issues on the interface of genetics and society, to develop consensus on policy matters in these fields and to transmit policy statements and opinions to appropriate parties. 